\title{
The Issue of 'Radical Otherness' in Contemporary Theories of Democracy and Citizenship Education
}

\section{Leiviskä, Anniina}

2018-08

Leiviskä , A 2018 , ' The Issue of 'Radical Otherness' in Contemporary Theories of Democracy and Citizenship Education ', Journal of Philosophy of Education , vol. 52 , no. 3 , pp. 498-514 . https://doi.org/10.1111/1467-9752.12338

http://hdl.handle.net/10138/327535

https://doi.org/10.1111/1467-9752.12338

unspecified

acceptedVersion

Downloaded from Helda, University of Helsinki institutional repository.

This is an electronic reprint of the original article.

This reprint may differ from the original in pagination and typographic detail.

Please cite the original version. 


\title{
The Issue of 'Radical Otherness' in Contemporary Theories of Democracy and Citizenship Education
}

\begin{abstract}
This paper examines the concept of 'radical otherness' from the perspectives of J ohn Rawls' political liberalism and Chantal M ouffe's agonistic pluralism, and studies the relevance of these approaches to contemporary citizenship education. In this context, the notion of 'radical otherness' refers to such ethical, political or religious doctrines that are incompatible with the basic principles of liberal democracy and thus present a potential challenge to democratic institutions. The paper suggests that despite its recent popularity in political philosophy and theory of education, M ouffe's agonistic pluralism faces difficulties in providing an adequate response to the issue of accommodating radical others in contemporary democratic societies. As a rejoinder to the Mouffean approach to political education, the paper develops a view of citizenship education based on Rawls' concept of reasonableness, and the democratic principles associated with it. It is argued in the paper that these principles - reciprocity and the burdens of judgment - are constituent elements of the symbolic space required by democratic politics. The paper further suggests, however, that to properly address the issue of radical otherness in contemporary democracies, the limitations of the Rawlsian approach must also be recognised. Accordingly, Rawls' theory needs to be complemented with a more critical understanding of the economic, social and political processes and mechanisms that currently create structural injustice and social and political inequality in contemporary democracies.
\end{abstract}

Keywords: radical otherness, democracy, political liberalism, agonistic pluralism, citizenship education, reasonableness

\section{Introduction}

The issue of "radical otherness"1 (e.g. Jezierska, 2015, p. 99; Gaon, 2009, p. 162) - the emergence of anti-democratic and illiberal political claims, views and goals within liberal democratic societies is particularly topical in the light of the political landscape of contemporary democracies. In many European countries the increasing support for far-right populist parties presenting nationalist, antiimmigration and even openly racist and xenophobic political views has raised questions concerning the boundaries of democratic participation and freedom of speech. After the sequence of terrorist attacks in Europe, and ISIL foreign fighters returning to their homelands, continuous worries have also been expressed regarding Islamic fundamentalism and the potential threat it poses to democracy and Western liberal values. The issue of radical otherness is also deeply intertwined with what has been recently characterised as the crisis of liberal democracy - a phenomenon or a series of phenomena symbolised by, and perhaps culminating in, events such as the Brexit referendum and the election of Donald Trump as president of the United States.

These events have evoked serious concerns regarding the future of liberal democracy and its central values and principles, the existence and permanence of which have been largely taken for granted. The political responses to these concerns have, so far, been reactionary and inadequate, and in many cases deeply prejudiced: we have witnessed, among other things, citizenship education initiatives to prevent political radicalisation among students with immigrant backgrounds, travel

\footnotetext{
${ }^{1}$ In the context of this paper, the notion of radical otherness has a totally different meaning than in poststructuralist philosophy (in the philosophies of Jacques Derrida and Emmanuel Levinas in particular) where the notion of radical otherness or alterity is utilized as an ethical concept.
} 
restrictions set up by the Trump administration and anti-immigration policies in many European countries. The politicians and administrations behind these initiatives and policies have generally ignored the fact that social and political marginalisation, exclusion and stigmatisation are among the major factors making individuals and groups vulnerable to political radicalisation. Moreover, they have also failed to recognise that right-wing populism itself poses a severe threat to the legitimacy of democracy. What is currently missing, and what is perhaps needed, is reasonable public discussion concerning central democratic principles and values, the limits of democratic participation, the legitimacy of different political claims and arguments, and the education of future citizens. Political philosophy and philosophy of education can provide a valuable starting point for this discussion.

In this paper, I focus on the question of how the issue of radical otherness can be addressed through education in the context of contemporary liberal democracies, and I examine this question particularly from the perspectives of agonistic and deliberative theories of democracy and citizenship education. By radical otherness, I refer to the representatives of ethico-political or "comprehensive doctrines" (Rawls, 2005, p. xvi) whose political claims are incompatible with the constitutive principles of liberal democracy. In the theories of democracy addressed in this paperJohn Rawls' political liberalism and Chantal Mouffe's agonistic pluralism - the notion of radical otherness is associated with the demarcation of the democratic regime, because including the claims and demands of radical others in democratic politics would potentially jeopardise the legitimacy of democratic institutions and processes. Rawls typically utilises the notions of "intolerant citizens" (1999, pp. 190-194) and "unreasonable doctrines" (1997, p. 802, 806) to refer to 'radical others' whose political claims are inconsistent with the political conception of justice and the central democratic principles outlined in his Political Liberalism (2005[1993]). In Mouffe's theory, these others are characterised as political "enemies" $(2000$, p. 13, 74$)$ who do not share in adhering to the principles of equality and liberty that constitute the democratic polity.

Mouffe's work offers a fruitful point of departure for discussing the issue of radical otherness, as her The Democractic Paradox (2000) and On the Political (2005) deal with the emergence of rightwing populist parties and different forms of ethnic, religious and political fundamentalism in contemporary European democracies. Mouffe argues that the rise of these movements is a symptom of the consensus politics practiced by these societies' predominant political parties, and particularly stems from the lack of significant political alternatives and channels through which political dissent can be expressed. Importantly, Mouffe (2005) binds her analysis of the political landscape of contemporary European democracies together with her influential critique of Rawls' and Jürgen Habermas' theories of deliberative democracy. She argues that the ideal of a fully inclusive public sphere involved in these theories may be utilised to legitimise the exclusion of alternative and marginal voices and identities from effective participation in democratic politics. M ouffe $(2000$, p. 96$)$ further suggests that the deprivation of the possibility to identify with valuable conceptions of democratic citizenship may result in finding channels of political identification outside the democratic regime, possibly even in fundamentalist movements. Therefore, one of the explicit aims of her political theory is to offer a democratic model that allows the free expression of political dissent, passions and conflict within democratic politics and thus presumably eliminates the need for violent political antagonism.

My aim in this paper is to demonstrate, first, that a democratic regime always requires establishing limits that cannot be violated without simultaneously jeopardising the legitimacy of democratic processes and institutions. I show that M ouffe's philosophy makes no exceptions, and that therefore her critique of Rawls' political liberalism is somewhat unjustified. In other words, also Mouffe's 
theory sets boundaries to democratic participation and thus her agonistic pluralism gives rise to the problem of radical otherness to which she is unable to provide a satisfactory answer. Second, I examine the issue of radical otherness in the context of citizenship education through the educational implications of Mouffe's and Rawls' theories of democracy. I first introduce Claudia Ruitenberg's (2009) application of M ouffe's agonistic pluralism to the field of political education. As a rejoinder to Ruitenberg, I then argue that although fostering political emotions and collective political identifications may constitute an important dimension of citizenship education, addressing the issue of radical otherness through education requires teaching democratic principles which allow students to develop a shared adhesion to the democratic regime. I also suggest that adherence to these principles is a necessary precondition for students to become political adversaries in the sense intended by Ruitenberg and Mouffe. Moreover, I defend the Rawlsian notion of reasonableness, and the associated principles of reciprocity and the burdens of judgment, as viable points of departure for contemporary citizenship education. Finally, however, I draw attention to the limitations of Rawlsian citizenship education by suggesting that education in democratic principles may be futile if the institutions of the society do not operate in concordance with these principles. Accordingly, the materialisation of the aims of democratic education depends on the proper institutionalisation of these democratic principles.

\section{Radical otherness in Rawls' political liberalism}

In Political Liberalism, Rawls' central concern is the question "How is it possible that there may exist over time a stable and just society of free and equal citizens profoundly divided by reasonable and yet incompatible religious, philosophical, and moral doctrines?" (Rawls, 2005, p. xviii). The central aim of Rawls' political theory is thus to explain how legitimate law-making and peaceful coexistence among citizens is possible in societies where people significantly differ in their views on how to organise their society together. Rawls' solution to this question rests upon a public, political conception of justice which is "free-standing" (Rawls, 2005, p. 10, 12-13) in the sense that it is derived from the public political culture of liberal democratic society rather than a particular comprehensive doctrine. Moreover, Rawls insists that instead of a mere modus vivendi, this conception is supported by an "overlapping consensus" (p. 144), meaning that it is rationally endorsed by the representatives of diverse comprehensive doctrines albeit for different reasons, i.e., reasons internal to these doctrines. The political conception of justice is thus a "module" ( $p$. 145) that fits into and can be supported by various comprehensive doctrines. It is therefore capable of providing mutual terms of cooperation without undermining moral, philosophical and religious pluralism.

Importantly, Rawls' political conception of justice depends on a presupposition of "reasonableness" (Rawls, 2005, p. 49), and it serves to protect reasonable rather than simple pluralism, the latter referring to unlimited or unconstrained pluralism. In other words, for Rawls the concept of reasonableness sets the limits to what beliefs, ideas and values can be reasonably accepted within a liberal democratic society consisting of a variety of different, sometimes even incommensurable comprehensive doctrines. The concept of reasonableness serves to protect the right of citizens to choose a way of life with no restraints other than other citizens' same right. The central value inherent to the concept of reasonableness is reciprocity, which refers to the idea that citizens are "ready to propose principles and standards as fair terms of cooperation and to abide by them willingly, given the assurance that others will likewise do so" (p. 49). Another central feature of reasonableness is an awareness of the "burdens of judgment" (p. 54), which means that citizens recognise that there is no single correct answer to complex ethical and political issues, and that different, albeit equally reasonable, responses can be given to such questions from different 
perspectives. What follows from these ideas is reasonable citizens recognising that they are not justified in using political power to repress or exclude from political participation other reasonable comprehensive doctrines, and not justified in imposing their own beliefs upon others (Rawls, 2005).

The idea of reasonableness described above raises the issue of radical otherness: while Rawls' political liberalism is sensitive to different forms of reasonable otherness - in other words, it accepts and affirms the plurality of reasonable comprehensive doctrines - it cannot easily accommodate forms of radical otherness, by which I mean political claims and arguments that are incompatible with the ideals of reciprocity and the burdens of judgment. As Rawls (1997) points out, political liberalism cannot engage with those who reject constitutional democracy and its central principles and ideals, and who thus have "a zeal to embody the whole truth in politics" (p. 767). For Rawls, the inclusion of such unreasonable or intolerant doctrines would potentially jeopardise the legitimacy and stability of the democratic regime, because their representatives are not willing to respect the equal right of others to hold the views, values and beliefs internal to their respective doctrines.

However, it is important to acknowledge the relatively modest scope of Rawls' political theory. Namely, the domain of political liberalism consists of the so-called "constitutional essentials" (Rawls, 2005, p. 214), by which Rawls refers to the political rights and liberties that may reasonably be included in a written constitution, as well as fundamental issues of justice, all of which are related to the basic structure of society. In addition to the political constitution, this basic structure includes the principal economic and social arrangements that determine the distribution of fundamental rights and duties and the division of the advantages that arise from social cooperation. Rawls' political liberalism thus presupposes that when these fundamental issues of justice are involved, citizens should strive to make their claims understandable to others by demonstrating how they can be supported by the political values inherent in public reason. This demand for public justification, however, does not extend beyond fundamental issues of justice, and thus Rawls' theory allows for political disagreement, conflict and appealing to non-public reasons when it comes to other political issues and questions.

This brings us back to the difference between reasonable otherness and radical otherness: for Rawls, radical others are those who are not willing to prioritise public reasons over private ones when addressing fundamental issues of justice. In contrast, reasonable others recognise that if they wish to maintain their inviolable right to hold the beliefs, values and practices internal to their own comprehensive doctrine, they must reciprocally recognise the equal right of other reasonable citizens. Rawls' presupposition of reasonableness thus serves to protect rather than erase plurality, and in order to do so, it must distinguish between reasonable doctrines compatible with the ideals of reciprocity and the burdens of judgment, on one hand, and unreasonable ones that reject these ideals and thus cannot be included in the liberal democratic regime without problems, on the other.

\section{Radical otherness in Mouffe's agonistic pluralism}

As mentioned in the introduction, Chantal M ouffe is one of the most influential critics of Rawls' and Habermas' theories of democracy and she famously presents her own agonistic pluralism as an alternative to them. One of the central aims of Mouffe's democratic theory is to restore the significance of conflict in democratic politics, following its role being downplayed by consensusoriented approaches to democracy. In Mouffe's view, deliberative democrats' emphasis on a neutral, impartial and all-inclusive public sphere primarily arises from their misguided understanding of the nature of "the political" (M ouffe, 2000, p. 101; 2005, p. 9). M ouffe derives her concept of "the political" (2005, pp. 14-15) from two primary sources, one being Carl Schmitt's political philosophy and the other the notion of "the constitutive outside" (p. 15) developed by 
Henry Staten (1985) on the basis of Jacques Derrida's philosophy. At the core of M ouffe's concept of the political is the view that the affirmation of difference - the recognition of something as 'other' - is a precondition for the existence of an identity, a 'me' or an 'us'. Identification thus involves drawing a line between oneself and the other, or the inside and "the constitutive outside" (M ouffe, 2005 , p. 15). As M ouffe (2005) explains, in Schmitt's political philosophy this 'identification-throughdifferentiation' gives rise to the view of the political as an antagonistic friend/enemy relation because every political order is constituted by the exclusion of those who are not accepted as a part of the uniform political community.

In On the Political (2005), Mouffe defines her democratic theory as an attempt to challenge consensus-based models of democracy by arguing "with Schmitt against Schmitt" (p. 14). Mouffe adopts from Schmitt the idea of the ever-present possibility of antagonism in political relations, and thus rejects what she claims to be the deliberative democrats' goal: the removal of conflict from the public sphere. M ouffe (2005) argues that considering the antagonistic nature of the political, this is a fundamentally unrealistic goal for democratic politics. She further claims that by denying the basic human need for collective political identification and the significance of political disagreement and conflict in democratic politics, the deliberative democratic enterprise might lead to destructive consequences. Namely, if excluded and marginalised voices are deprived of the possibility of identifying with valuable conceptions of democratic citizenship, they are likely to find other channels of collective identification outside the democratic regime. Accordingly, in her central works, Mouffe $(2000,2005)$ identifies the emergence of right-wing political parties and various forms of religious, moral and ethnic fundamentalism with the failure of democratic politics to provide sufficiently diverse channels of political identification.

However, Mouffe $(2000,2005)$ departs from Schmitt in her attempt to integrate pluralism as a part of her political theory: she argues that political identification must not always take the form of a friend/enemy relation that calls for a uniform political community. Hence, the aim of Mouffe's democratic theory is to redefine the we/they relation underlying all political association in a way that is compatible with democratic pluralism. Mouffe therefore suggests that the proper task of democratic politics is to enable a transition from violent conflict between enemies to a friendly struggle between political "adversaries" (Mouffe, 2000, pp. 114-117), and thus to transform political antagonism into democratic "agonism" (p. 117), which no longer threatens the existence of the democratic regime. What enables the transition from antagonism to agonism, and the transformation of political enemies to legitimate political adversaries, is a joint adhesion to the central ethico-political principles of liberal democracy: liberty and equality (M ouffe, 2000, p. 102). According to Mouffe, these principles constitute for the members of the democratic polity a common symbolic space to which all citizens must be committed although they may disagree on the interpretation and implementation of these principles. Democratic politics thus consists of a nonviolent but nevertheless vibrant and passionate conflict between different interpretations.

For M ouffe, recognising the existence of conflicting interpretations of democratic principles and perceiving the borders of the democratic polity as being politically constituted play a crucial role in circumventing the need for open hostility and political violence. Namely, allowing for the expression of political dissent within democratic politics and opening the borders of the democratic polity to renegotiation and redefinition allegedly eliminate the need for marginalised political voices to find forms of political identification outside the democratic order, for example in extremist or antidemocratic movements. Mouffe's major criticism of Rawls is thus associated with the Rawlsian understanding of the moral or rational foundation of a liberal democratic constitution. As noted above, in Rawls' (2005) view, the liberal democratic order cannot be endorsed as a mere modus 
vivendi because this would endanger both the legitimacy and stability of the democratic regime. Mouffe (2000) argues, however, that Rawls merely presents as a moral exigency what is really a political decision, and thus labels radical others as "unreasonable" (p. 24) instead of recognising their exclusion as a purely political decision.

However, defining the demarcation between members and non-members of the democratic polity as a political decision does not eliminate the fact that establishing a democratic regime requires such demarcation. Accordingly, as M athias Thaler (2010) points out, M ouffe cannot fully escape the issues faced by deliberative democrats because by introducing a measure to hold legitimate forms of contestation apart from illegitimate ones - the principles of equality and liberty that constitute the shared symbolic space of a democratic community - Mouffe also sets limits on democratic participation that cannot be disregarded without jeopardising the democratic regime. Hence, while the goal of democratic politics is to 'tame' the antagonism inherent in the political, M ouffe clearly recognises that this does not always succeed, and that in liberal democratic societies there are always political "enemies" whose existence and participation present a threat to the democratic polity. Agonistic pluralism thus also gives rise to the category of radical otherness consisting of those who do not adhere to at least some interpretation of democratic principles and who therefore cannot be included in the democratic regime, at least not without altering or disregarding the core principles of liberal democracy. The following citation illuminates Mouffe's point of view on this issue:

I do not believe that a democratic pluralist politics should consider as legitimate all the demands formulated in a given society. The pluralism that I advocate requires discriminating between demands which are to be accepted as part of the agonistic debate and those which are to be excluded. A democratic society cannot treat those who put its basic institutions into question as legitimate adversaries. The agonistic approach does not pretend to encompass all differences and to overcome all forms of exclusions. But exclusions are envisaged in political and not in moral terms. Some demands are excluded, not because they are declared to be 'evil', but because they challenge the institutions constitutive of the democratic political association. To be sure, the very nature of those institutions is also a part of the agonistic debate, but, for such a debate to take place, the existence of a shared symbolic space is necessary (M ouffe, 2005, pp. 120-121).

Hence, although M ouffe understands the grounds for excluding radical others differently from the deliberative democratic approaches, her theory also involves others whose exclusion is necessary for protecting the stability of the democratic regime. Accordingly, M ouffe is unable to circumvent what Lasse Thomassen (2006) refers to as the "aporetic" (p. 452) nature of democracy: in order to sustain the central democratic principles and protect democracy against intolerance and inequality, a democratic polity must paradoxically exclude those who are not willing to adhere to its central values and principles. From the perspective of Mouffe's theory, this aporia seems particularly problematic as she herself associates exclusion from democratic participation with the emergence of ethico-political fundamentalism.

From the perspective of the issue of radical otherness, the primary question is whether the excluded can be engaged in any meaningful way within the framework of agonistic pluralism. M ouffe provides no satisfactory answer to this question. Rather, it seems that agonistic pluralism sets the stage for even stronger political antagonisms between democratic citizens and radical others than the theories of deliberative democracy, because of its reliance on Schmitt's political ontology where the excluded are identified as political 'enemies' who present an immediate threat to democratic institutions. In what follows, I elaborate on why the theories of deliberative democracy might 
actually provide a better point of departure for coming to terms with radical otherness in contemporary liberal democracies than their agonistic alternative.

\section{Addressing the issue of radical otherness in contemporary liberal democracies}

Some of the passages in Rawls' work where he addresses the issue of "intolerant citizens" (1999, pp. 190-194) or "unreasonable doctrines" (1997, pp. 801-802) in liberal democratic societies indicate that he might actually be proposing a much more tolerant treatment of radical others than M ouffe. Rawls (1999, p. 193) suggests it is only when unreasonable doctrines become so strong that they threaten the stability of the democratic regime that direct actions on the part of the polity are justified. He points out that in these cases the right form of conduct depends on the particular political and social circumstances, and thus it becomes a practical dilemma that philosophy alone cannot resolve. Moreover, Rawls (1999) argues that protecting the liberties of the intolerant and granting them equal rights as citizens might gradually result in an increased adherence of these citizens to liberal principles and institutions. In other words, Rawls believes that living in a liberal state for a longer period of time has the transformative potential to convert the intolerance of unreasonable people into tolerance, and build their trust in liberal democratic principles and institutions.

Consequently, if one accepts M ouffe's claim that political exclusion makes the excluded susceptible to radicalisation, the more tolerant approach represented by Rawls might help to prevent such consequences. However, perhaps a more compelling reason to prioritise the deliberative democratic position is that whereas Mouffe's theory focuses on subject positions and political identities and thus evokes the question 'Who can be included in democratic politics?', Rawls primarily emphasises the legitimacy of political arguments in deciding matters of public interest. As indicated above, Rawls' view is that political decisions on fundamental issues of justice must be justified exclusively on the basis of arguments and reasons that all reasonable citizens can be expected to accept. This focus on the legitimacy of political arguments is also at the core Habermas' theory of deliberative democracy and its democratic principle, which demands that legitimate legal norms should ideally regulate matters in the equal interest of all those affected (see Habermas, 1996). ${ }^{2}$ Therefore, from the perspective of radical otherness, the strength of the deliberative approach is that instead of excluding, on the basis of political identity, some actors at the outset, intolerant or anti-democratic views and claims can at least in principle be invited into such processes of public deliberation where views of this nature can be tested, criticised and even revised. M oreover, as Habermas (1996, p. 341) points out, if processes of rational deliberation and decisionmaking are properly institutionalised, only 'valid' proposals would ideally pass through the filter of political discourses and fair bargaining. The proper institutionalisation of procedures of rational deliberation thus relieves the requirement for rationality or reasonableness on the part of individual actors, and places it more directly on the institutions of the society thereby allowing for a more tolerant approach to particular individuals and groups.

It is evident, however, that numerous issues are impeding the adequate institutionalisation and implementation of principles of justice and procedures of rational deliberation in today's democratic societies, and these issues not only threaten the legitimacy of the political system but also erode citizens' trust in the workings of democracy. In addition to the issues mentioned in the introduction, many democratic societies are afflicted by corruption and unjust policies and

\footnotetext{
${ }^{2}$ M ore specifically, the democratic principle is formulated in Habermas' Between Facts and Norms (1996) as follows: "only those statutes may claim legitimacy that can meet with the assent (Zustimmung) of all citizens in a discursive process of legislation that in turn has been legally constituted" (Habermas, 1996, p. 110).
} 
practices, and their institutions operate in ways that give rise to different forms of social and political inequality as well as structural injustice. Hence, despite the long-term improvements in terms of social justice and equality, contemporary liberal democracies struggle to arrange the basic institutions of society in a manner that corresponds to their citizens' sense of justice, and this is reflected in citizens' unwillingness to engage in democratic politics and support the political alternatives available in the prevailing democratic order. For instance, recent studies associate the rise of support for right-wing populism with the increased social inequalities following economic globalisation and its national repercussions, such as economic deregulation and privatisation (e.g. Betz, 2005; Salmela \& von Scheve, 2017). It thus appears that overcoming the alienation from democracy and democratic politics experienced by many citizens requires more effective measures to recognise and intervene in the economic, social and political mechanisms that underlie unjust policies and practices.

In the next part of the paper, I discuss the implications of deliberative and agonistic theories of democracy for citizenship education with the aim of shedding light on the significance of education in addressing the issue of radical otherness. Although educational institutions and practices cannot be single-handedly responsible for responding to issues of legitimacy and justice associated with the democratic polity, education is nevertheless one of the key institutions of democratic society, and plays an important role especially in instilling democratic principles and creating a strong civil society capable of influencing political decision-making.

\section{Citizenship education and the issue of radical otherness}

Mouffe's theory of agonistic pluralism has recently been met with increasing interest in the philosophy of education. Claudia Ruitenberg's (2009) article "Educating political adversaries: Chantal Mouffe and radical democratic citizenship education" is among the most elaborate attempts to apply the central ideas of Mouffe's theory to the field of education, and I therefore mainly focus on her arguments in this section. ${ }^{3}$ Ruitenberg builds her argumentation upon M ouffe's critique of Rawls' political liberalism and further utilises this critique in her analysis of Eamonn Callan's (1997) theory of citizenship education. Ruitenberg's central claim is that political emotions, passions and collective identifications play a crucial role in the formation of democratic political agency, and therefore these features should be properly incorporated into political education. Ruitenberg's argument is partly based on Mouffe's idea that the elimination of fundamental convictions, political passions and loyalties from democratic politics might actually lead to destructive political antagonisms because their suppression only delays their manifestation and does not remove them. Accordingly, Ruitenberg argues that instead of focusing on civic virtues and skills of reasoning, political education should better take into account the basic human desire to belong to collectives, and the associated political emotions. She particularly takes issue with the centrality of the Rawlsian idea of the burdens of judgment in Callan's theory of citizenship education, and argues that through this conception, political conflict becomes mistakenly presented as an "imperfection" or a "hazard" (Ruitenberg, 2009, p. 275) rather than something constitutive of collective political existence. Ruitenberg's proposal, therefore, is that political education should enable students to become political adversaries capable of expressing political passions and conflict through democratic channels, and that this is best achieved through fostering political emotions and strengthening collective political identifications.

\footnotetext{
${ }^{3}$ In addition to Ruitenberg, M ouffe's theory of agonistic pluralism has been applied to the field of citizenship education by Gert Biesta (2009, 2011), Sharon Todd (2010) and M ichalinos Zembylas (2011).
} 
Ruitenberg's arguments bear directly on my discussion of the concept of radical otherness because, along the lines of M ouffe, Ruitenberg associates the emergence of radical forms of otherness with the deliberative democratic attempt to eradicate political conflict from the public sphere. While I recognise certain strengths in Ruitenberg's view of political education - to which I will return shortly - I also see significant shortcomings, which in my view are rooted in the deficiencies of M ouffe's agonistic pluralism. As I demonstrated above, according to Mouffe a democratic polity emerges when a common symbolic space, which is constituted by shared democratic principles of equality and liberty, is established. However, neither Mouffe nor Ruitenberg sufficiently explains how such symbolic space is constituted or how the antagonism involved in the political may be transformed into respectful democratic agonism. Moreover, what is it that motivates such a transition under conditions of pluralism, where there is no shared political identity, to unite the representatives of different, sometimes even incommensurable doctrines? In my view, the appropriate answer cannot be found in Ruitenberg's model of political education, which focuses on the idea of fostering political emotions and passions that are in line with particular political collectives. Rather, it seems that political education that seeks to raise political passions towards particular doctrines might strengthen the polarisation between different political groups and collectives and, in the worst case, even give rise to political antagonisms. Especially in the case of students having backgrounds in illiberal doctrines, strengthening their identification with these doctrines is likely to widen the gap between their values and beliefs and the predominant liberal democratic culture, which in turn might lead to even further marginalisation and isolation of these students.

Hence, against Ruitenberg it can be argued that the primary task of political education is to reinforce students' adherence to the core principles and values of democratic society, because it is ultimately this adhesion that creates a democratic space in which students are able to encounter each other as legitimate political adversaries in the first place. In my view, the value of Rawls' political liberalism lies precisely in its attempt to demonstrate how establishing a shared public sphere is possible in circumstances where there is no homogenous political identity to build upon. In Rawls' view, it is possible by virtue of citizens' reasonableness and particularly by their commitment to reciprocity the ability and willingness to propose and abide by fair terms of co-operation - as well as their awareness of the burdens of judgment. Accordingly, I suggest that teaching these principles is a central concern for citizenship education not only within the deliberative democratic framework but in all forms of education that seek to reinforce democratic political organisation under conditions of pluralism. I agree with Ruitenberg that fostering political emotions, passions and collective political identifications may be an important dimension of citizenship education especially when it comes to marginalised or suppressed political identities and voices; however, these emotions and identifications serve democracy and democratisation only in so far as they cohere with public standards of legitimacy.

Moreover, in contrast to Rawls (1999), who believes that living in a liberal state for a longer period of time is sufficient for creating a commitment to liberal democratic principles, I suggest that these principles and the associated civic virtues must be consciously fostered through appropriate citizenship education. As Victoria Costa (2011, pp. 59-60) points out, although Rawls recognises the role of education in the creation of reasonable citizens, he does not sufficiently emphasise this role because of his confidence in the functioning of just institutions spontaneously generating the necessary support for liberal political conceptions of justice. As Costa (ibid.) further suggests, this confidence may be plausible if one is imagining the workings of an ideal society in which the major social institutions satisfy the principles of justice. However, because actual social, political and economic institutions are far from ideal, as noted above, the formation and maintenance of common democratic culture requires institutions and practices that are specifically designed to 
foster democratic principles. Educational institutions such as common schools are in a privileged position to teach these principles, because schools are responsible for a significant portion of children's education, and school education can be planned and publicly monitored in ways that are not feasible for other institutions, such as the family (e.g. Callan, 1997; Kymlicka, 2001).

So far, I have argued that citizenship education - also agonistic - should primarily focus on fostering reasonableness and the associated principles of reciprocity and the burdens of judgment because they play a crucial role in enabling the emergence of a common symbolic space presupposed by democratic politics. However, from the viewpoint of justifying education, it is important to examine the nature of these principles in more detail. This is particularly crucial with regard to Rawls' political liberalism, as it has been accused of presenting ideological and political aspirations as moral exigencies (M ouffe, 2000). Rawls' theory of justice has also been regarded as being ignorant of such socially and politically decisive features as race and gender (e.g. Mills, 2005). So the important question is whether Rawlsian "reasonableness" (Rawls, 2005, p. 49) can be seen as having a rational basis, which means that there are good reasons to prefer it as a criterion of democratic legitimacy and as an educational aim over other, illiberal principles. Or should it rather be seen as a result of a successful use of political power, and merely as serving to legitimise the present hegemonic configuration as suggested by M ouffe $(2000,2005)$ and Charles Mills $(2005)$, among others? Firstly, it is important to point out that if the principles that set the frontiers of a democratic regime are seen as a mere modus vivendi or as politically determined, as M ouffe (2005, pp. 120-121) suggests, it must also be accepted that these principles may undergo a significant transformation whenever the balance of power shifts in society. In other words, if intolerant, illiberal or authoritarian political views gain political preponderance in a previously liberal democratic society, from the point of view of agonistic pluralism there are no rational grounds for criticising such a transformation. This is because the prevailing liberal democratic order is merely "a contingent and temporary hegemonic articulation of 'the people'" (M ouffe, 2000, p. 49).

Could this conclusion be avoided by arguing that there are good reasons to favour reasonableness as a central democratic principle and as an aim of democratic education? To respond to this question, I loosely follow Brian Barry's (1994) defence of Rawls' political liberalism: according to Barry, the "fact of pluralism" (p. 329) alone provides good reasons to favour Rawlsian reasonableness over principles that are based, for instance, on particular comprehensive doctrines. ${ }^{4}$ Namely, according to Barry (1994), there is no particular conception of 'the good' that cannot be reasonably rejected by representatives of other doctrines. Reasonableness itself, however, cannot be reasonably rejected by anyone who wants to maintain the right to choose their way of life and who wishes that this way of life not be discriminated against by the political constitution or basic institutions of society. If we apply this idea to the context of citizenship education, it can be argued that the principles associated with Rawlsian reasonableness - reciprocity and the burdens of judgment - can be favoured for good reason under conditions of pluralism simply because cultivating principles associated with a particular comprehensive doctrine might discriminate against, marginalise or violate the rights of representatives of other comprehensive doctrines. Accordingly, I suggest that fostering reasonableness is justified even though it is not entirely 'neutral' in the sense that it strengthens liberal and tolerant political views while weakening intolerant and illiberal ones. As Costa (2011) points out, Rawlsian citizenship education is potentially harmful to antidemocratic, intolerant and dogmatic doctrines because instilling political principles associated with political liberalism tends to evoke a critical attitude towards conceptions of the good

\footnotetext{
${ }^{4}$ Instead of reasonableness, Barry (1994) refers to Rawlsian "constitutional neutrality" (p. 325) but the logic underlying his defense is similar to the one employed in this article.
} 
that sustain them. However, I agree with Costa that if teaching Rawlsian principles erodes the basis for belief in dogmatic or intolerant views, this is not something to be criticised but rather something in favour of the proposal.

To return to the issue of radical otherness, I therefore suggest that citizenship education which focuses on the principle of reasonableness plays an important role in integrating different ethicopolitical views and doctrines into the common democratic culture, and thus helps to prevent political marginalisation. Students should be taught to perceive and examine ethical and political issues and questions from the perspective of legitimacy - that is, public defensibility - because this creates conditions for cooperation and reciprocity across cultural, political and religious differences. More importantly, by instilling democratic principles and fostering capabilities of rational argumentation and public reasoning, citizenship education that builds upon the principle of reasonableness can help to establish and support a vibrant, democratic public sphere and civil society. This way, issues of legitimacy and justice can be brought from the margins of society to the centre of the political system. Citizenship education can therefore have an instrumental role in transforming unjust practices that erode citizens' faith in the democratic system. Thus it may also prevent the development of anti-democratic attitudes as well as inhibit the need to resort to nondemocratic channels of political influence.

However, it is important to recognise that teaching democratic principles may be futile or, in the worst case, even become a rhetorical means of justifying de facto social inequality if the democratic principles and procedures of rational deliberation are not properly implemented in the institutions and practices of society. As I pointed out earlier, while liberal democracies normally grant their citizens equal rights and liberties on the level of constitution and legislation, in reality their economic, political and social institutions and practices often fail to meet what justice demands. In some cases, the experienced injustices and inequalities may result in the inability or unwillingness of citizens to identify with the core principles of democracy, to take part in procedures of rational deliberation or defend their political views by appealing to publicly acceptable reasons. Accordingly, while Rawlsian citizenship education can provide a fruitful starting point for promoting democratic citizenship and creating a healthy democratic culture, adequately responding to the issue of radical otherness in contemporary democracies requires dealing with the structural injustices and unjust practices and policies that make citizens vulnerable to social and political marginalisation.

The evident strength of Ruitenberg's account of political education, therefore, is that it explicitly aims to address society's existing injustices and inequalities through political education that makes effective use of political passions and emotions. In this sense, while I insist that citizenship education must encourage students' commitment to public standards of cooperation and rational deliberation, I agree with Ruitenberg that political education should also provide students with means to resist social structures and institutional practices that conflict with citizens' sense of justice. In this sense, citizenship education that takes the issue of radical otherness seriously should encourage students to participate in the functioning of civil society, and should also address the possibility of engaging in non-violent forms of civil disobedience. Namely, the current political atmosphere in contemporary liberal democracies gives little reason to believe in public reasoning or the persuasive force of a better argument. Significant political change might indeed require fostering political passions and collective political identifications towards such liberal democratic positions that aim to provide an alternative especially to right-wing populism and radical right discourses.

\section{Conclusions}


In her most well-known works, Mouffe $(2000,2005)$ argues that because the deliberative democratic model does not allow for the expression of political conflict within the public sphere, it creates conditions for the outbreak of political antagonisms through non-democratic channels. Accordingly, she claims that the orientation towards consensus is at least partly responsible for the rise of different forms of radical otherness in Western liberal democracies. In this article, my attempt has been to demonstrate that Mouffe's critique is somewhat unjustified: namely, establishing a democratic polity always requires setting criteria of validity to hold legitimate political claims and conflicts apart from illegitimate ones. This applies equally to deliberative and agonistic approaches to democracy. Accordingly, both of these approaches face difficulties in engaging those who must be excluded from democratic politics due to their illegitimate political claims. Moreover, I have also suggested that Mouffe's agonistic approach might ultimately give rise to even stronger political antagonisms between democratic citizens and radical others than Rawls' political liberalism, as it labels the excluded as political enemies who are automatically perceived as threats to the existence of the democratic polity.

In my proposal for citizenship education I examined Claudia Ruitenberg's application of M ouffe's agonistic pluralism to the field of political education. I argued that fostering political emotions, passions and collective identifications must be preceded and accompanied by education in such democratic principles that enable the emergence of a common (democratic) symbolic space in the first place. Adherence to democratic principles and the attendant commitment to the common project of constructing and sustaining a shared public sphere play a key role in preventing the emergence of political antagonisms associated with radical forms of otherness. I further suggested that modern liberal democracies' 'fact of pluralism' gives good reason to accept the Rawlsian principle of reasonableness as a point of departure for contemporary citizenship education. However, I also emphasised that reinforcing students' commitment to the shared democratic principles might be futile if the implementation of these principles in society's institutions is not properly ensured. The current political circumstances in Western democratic societies clearly demonstrate how limited the possibilities of education are to promote democracy, equality and justice when citizens are confronted with discrimination, unjust practises and policies as well as different forms of structural injustice in their everyday lives. Accordingly, I suggest that contemporary theory of citizenship education must also recognise the limits of Rawlsian political theory and pair it with a more critical understanding of the economic, social and political structures and processes that give rise to such experiences of inequality and injustice that render citizens vulnerable to political marginalisation and radicalisation.

\section{References}

Barry, B. (1994). In Defense of Political Liberalism. Ratio Juris, 7(3), pp. 325-330.

Betz, H. G. (2005). Against the system: Radical right-wing populism's challenge to liberal democracy. In: J. Rydgren, ed., M ovements of Exclusion: Radical Right-Wing Populism in the Western World. Hauppauge, NY: Nova Science Publishers, pp. 25-40.

Biesta, G. (2009). Sporadic democracy: Education, democracy, and the question of inclusion. In: M. Katz, S. Verducci and G. Biesta, eds., Education, Democracy and the M oral Life. Dodrecht: Springer, pp. 101-112.

Biesta, G. (2011). The Ignorant Citizen: M ouffe, Rancière, and the Subject of Democratic Education. Studies in Philosophy and Education, 30(2), pp. 141-153.

Callan, E. (1997). Creating Citizens: Political Education and Liberal Democracy. Oxford: Clarendon Press.

Costa, V. (2011). Rawls, Citizenship, and Education. New York and London: Routledge. 
Gaon, S. (2009). Democracy in Crisis: Violence, Alterity, Community. Manchester and New York: Manchester University Press.

Habermas, J. (1996). Between Facts and Norms: Contributions to a Discourse Theory of Law and Democracy, trans. William Rehg. Cambridge, MA: The M IT Press.

Jezierska, K. (2015). "I" meets the "Other": Agonistic and deliberative versions of subjectivity and otherness. In: K. Jezierska and L. Koczanowicz, eds., Democracy in Dialogue, Dialogue in Democracy: The Politics of Dialogue in Theory and Practice. London and New York: Routledge, pp. 99-120.

Kymlicka, W. (2001). Politics in the Vernacular: Nationalism, Multiculturalism, and Citizenship. Oxford: Oxford University Press.

M ills, C. W. (2005). "Ideal theory" as ideology. Hypathia, 20(3), pp. 165-184.

M ouffe, C. (2000). The Democratic Paradox. London: Verso.

M ouffe, C. (2005). On the Political. London and New York: Routledge.

Rawls, J. (1997). The Idea of Public Reason Revisited. The University of Chicago Law Review, 64(3), pp. 765-807.

Rawls, J. (1999[1971]). A Theory of Justice, revised edition. Cambridge, MA: The Belknap Press of Harvard University Press.

Rawls, J. (2005[1993]). Political Liberalism, expanded edition. New York and Chichester, West Sussex: Columbia University Press.

Ruitenberg, C. (2009). Educating Political Adversaries: Chantal M ouffe and Radical Democratic Citizenship Education. Studies in Philosophy and Education, 28(3), pp. 269-281.

Salmela, M. and von Scheve, C. (2017). Emotional Roots of Right-wing Political Populism. Social Science Information, 56(4), pp. 567-595.

Staten, H. (1985). Wittgenstein and Derrida. Oxford: Basil Blackwell.

Thaler, M . (2010). The Illusion of Purity: Chantal M ouffe's Realist Critique of Cosmopolitanism. Philosophy and Social Criticism, 36(7), pp. 785-800.

Thomassen, L. (2006). The Inclusion of the Other? Habermas and the Paradox of Tolerance. Political Theory, 34(4), pp. 439-462.

Todd, S. (2010). Living in a Dissonant World: Toward an Agonistic Cosmopolitics for Education. Studies in Philosophy and Education, 29(2), pp. 213-228.

Zembylas M. (2011). Ethnic Division in Cyprus and a Policy Initiative on Promoting Peaceful Coexistence: Toward an Agonistic Democracy for Citizenship Education. Education, Citizenship and Social Justice, 6(1), pp. 53-67. 